\title{
Blood Chemistry Measurement
}

National Cancer Institute

\section{Source}

National Cancer Institute. Blood Chemistry Measurement. NCI Thesaurus. Code C47868.

The determination of the measured concentrations of chemical constituents of the blood by assay in a clinical laboratory. 